\title{
ANALISA DAN USULAN STRATEGI PEMASARAN DENGAN METODE QSPM (Studi Kasus Pada UMKM Di Bandung: Pakan Ikan Waringin Bandung)
}

\author{
Caroline ${ }^{1}$ \\ Laura Lahindah ${ }^{2}$ \\ 1,2 Program Magister Manajemen, Program Pascasarjana, Universitas Katolik \\ Parahyangan Bandung, Jalan Merdeka no. 30, Bandung 40117, Jawa Barat
}

\begin{abstract}
Currently, the fish supply in Indonesia comes from aquaculture fishery (FAO, 2005). The success of fishery aquaculture production is strongly influenced by the availability of fish feed. PD Waringin is a local fish feed producer located in Bandung which is experiencing problems in marketing. The research was conducted to propose alternative marketing strategy $P D$ Waringin. The required data is obtained through in-depth interviews with the owner and distributing questionnaires to consumers. The data obtained are then analyzed using a Comprehensive Strategy Formulation Framework that involves analysis tools such as EFE matrix, IFE matrix, SWOT matrix, and QSPM matrix. The results of the QSPM matrix analysis show that the most interesting strategy is the SO (StrengthOpportunities) strategy, which is to do product development, improve efficiency, optimize growth and sales and increase productivity.
\end{abstract}

Keywords: marketing strategy, Comprehensive Strategy Formulation Framework, fish feed

\section{PENDAHULUAN}

Perikanan budidaya merupakan komponen penting dari perikanan Indonesia yang memberikan kontribusi untuk keamanan pangan nasional, pendapatan dan penciptaan lapangan kerja dan pendapatan devisa negara (Food Agriculture Organization, 2005). Berdasarkan data Kementrian Kelautan dan Perikanan (2016), pada tahun 2014 Indonesia memiliki total area yang dimanfaatkan untuk budidaya perikanan seluas 1,25 juta hektar dengan volume produksi ikan budidaya sebanyak 14,2 juta ton. Menurut Slamet Soebjakto, Direktur Jenderal Perikanan Budidaya Kementerian Kelautan dan Perikanan, produksi ikan hasil budidaya akan naik terus di tahun-tahun mendatang karena luasnya wilayah budidaya ikan di Indonesia. 
Pada tahun 2017, Kementerian Kelautan dan Perikanan memasang target ekspor produk perikanan sebesar US\$ 7,62 miliar. Nilai ini hampir dua kali lipat dari pencapaian ekspor dari bulan Januari sampai November 2016 yaitu sebesar US\$ 3,78 miliar dengan volume ikan sebanyak 978,33 ribu ton (Putra, 2016). Pencapaian target ekspor produk perikanan tentunya harus diimbangi dengan produksi perikanan di dalam negeri. Keberhasilan produksi perikanan budidaya ikan, khususnya perikanan air tawar dipengaruhi oleh ketersediaan pakan ikan.

Pakan ikan dibedakan menjadi 2 jenis yaitu pakan alami dan pakan buatan. Pakan alami biasanya diperoleh langsung dari alam tanpa melalui proses pengolahan. Sedangkan pakan buatan merupakan pakan yang dibuat dengan formulasi tertentu, baik nabati maupun hewani. Pakan buatan biasanya dibuat di pabrik dan dijual secara komersial atau bisa juga membuatnya sendiri. Dalam lingkungan budidaya, ikan lebih tergantung pada pakan buatan.

Salah satu permasalahan dalam budidaya ikan adalah tingginya biaya penyediaan pakan ikan sehingga mengurangi keuntungan yang didapatkan oleh petani ikan. Menurut Slamet Soebjakto, biaya penyediaan pakan berkontribusi antara 70\% - 80\% dari biaya produksi peternak ikan budidaya, dimana sebagian besar pakan ikan diperoleh dari pabrik-pabrik besar. Tingginya harga pakan ikan disebabkan karena kebutuhan pakan dan bahan baku pakan ikan buatan di Indonesia sebagian besar masih dipenuhi oleh produk impor salah satunya adalah impor tepung ikan.

Salah satu upaya Kementrian Kelautan Perikanan dalam mendorong penurunan harga pakan adalah melalui program Gerakan Pakan Ikan Mandiri (Gerpari). Gerpari merupakan gerakan untuk mendorong kemandirian kelompok agar dapat memproduksi pakan dan mengembangkan bahan baku pakan lokal serta penyediaan sarana produksi pakan secara mandiri. Indonesia memiliki sumber daya alam yang sangat mendukung untuk pengembangan pakan ikan mandiri guna mengurangi ketergantungan akan pakan pabrikan yang sangat bergantung kepada bahan baku impor.

Usaha pakan ikan lokal seringkali mengalami hambatan dalam pemasarannya. Saat ini pakan ikan buatan pabrik lebih diminati oleh pembudidaya ikan. Pakan ikan buatan pabrik dianggap memiliki kualitas yang lebih baik. Meskipun demikian, pakan ikan buatan pabrik memiliki harga yang lebih mahal karena bahan bakunya sebagian besar didapatkan melalui impor. Harga pakan yang mahal akan meningkatkan biaya produksi dan tentunya akan mengurangi keuntungan yang bisa didapatkan oleh pembudidaya ikan.

Salah satu produsen pakan ikan di Bandung adalah PD Waringin. Pakan ikan yang diproduksi oleh PD Waringin berasal dari bahan baku lokal seperti dedak padi, tepung ikan, tepung darah sapi, tepung jagung,bungkil kelapa dan 
bungkil kedelai. Penggunaan bahan baku lokal membuat harga pakan ikan buatan PD Waringin menjadi murah daripada pakan ikan buatan pabrik. Saat ini PD Waringin juga mengalami permasalahan dalam pemasaran produk pakan ikan. Selama ini perusahaan menjalankan bisnis sesuai dengan kebutuhan tanpa melakukan perencanaan strategi pemasaran yang matang.

\section{Gambar 1}

Penjualan Pakan Ikan PD Waringin Tahun 2006 - 2016 dalam ton

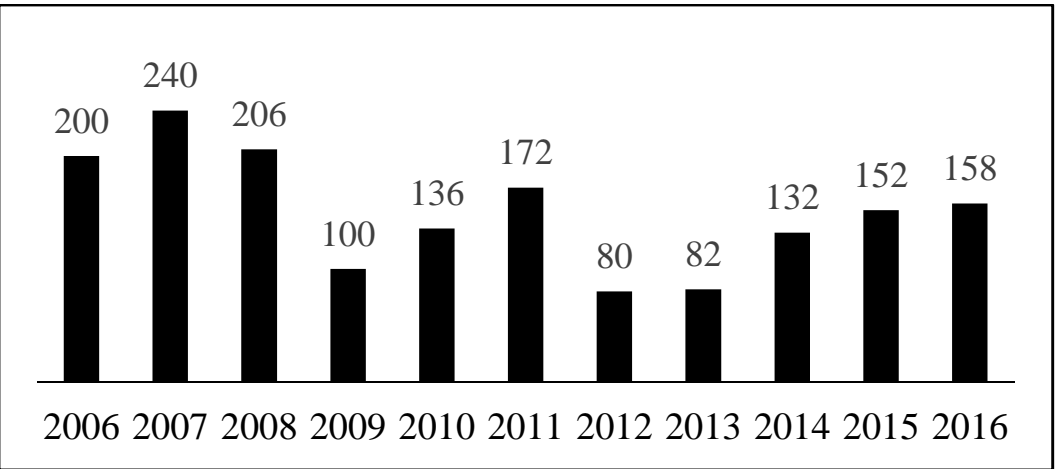

Sumber: Internal perusahaan, 2017

Jika dilihat dari data penjualan selama 10 tahun terakhir, penjualan tahunan pakan ikan PDW cenderung tidak stabil dan beberapa kali mengalami penurunan penjualan. Pada tahun 2012 hingga 2016, total penjualan mengalami kenaikan di tiap tahunnya namun kenaikan tersebut tidak terlalu signifikan. PD Waringin sebagai salah satu pelaku usaha pakan ikan saat ini belum memiliki strategi pemasaran yang cukup jelas untuk menghadapi berbagai persaingan sehingga dalam hal ini penulis ingin melakukan penelitian terhadap strategi pemasaran yang telah dijalankan perusahaan terhadap produk pakan ikan dan mencoba untuk mengusulkan strategi pemasaran baru berdasarkan kondisi yang sedang dihadapi perusahaan.

\section{TELAAH PUSTAKA}

\section{Strategi Pemasaran}

Menurut Kotler (2002), pemasaran secara sosial didefinisikan sebagai proses sosial dimana individu dan kelompok mendapatkan apa yang mereka butuhkan dan inginkan melalui penciptaan, penawaran, dan pertukaran produk dan jasa yang bernilai dengan orang lain. Sedangkan secara manajerial pemasaran didefinisikan sebagai seni menjual produk. Strategi pemasaran dalam organisasi menggambarkan bagaimana perusahaan akan memenuhi kebutuhan 
dan keinginan konsumen. Sebuah strategi pemasaran dapat terdiri dari satu atau lebih program pemasaran; setiap program terdiri dari dua elemen, yaitu target pasar dan bauran pemasaran atau marketing mix. Bauran pemasaran dikenal juga dengan istilah 4P, yaitu product, price, place, dan promotion. Untuk mengembangkan strategi pemasaran, organisasi harus memilih kombinasi yang tepat dari target pasar dan bauran pemasaran dalam rangka menciptakan keunggulan kompetitif yang berbeda dari para pesaingnya (Ferrel, 2011).

\section{Comprehensive Strategy Formulation Framework}

Comprehensive Strategy Formulation Framework merupakan sebuah teknik untuk memformulasikan strategi yang dapat diintegrasikan ke dalam sebuah kerangka berpikir yang terdiri dari tiga tahap. Alat-alat dalam kerangka berpikir ini dapat diaplikasikan untuk semua ukuran dan jenis organisasi dan dapat membantu pembuat strategi untuk mengidentifikasi, mengevaluasi dan menentukan strategi dari alternatif-alternatif strategi yang muncul.

Tabel 1

The Strategy-Formulation Analytical Framework

\begin{tabular}{|c|c|c|c|c|c|}
\hline \multicolumn{6}{|c|}{ The Input Stage } \\
\hline \multicolumn{2}{|c|}{$\begin{array}{c}\text { External Factor } \\
\text { Evaluation }(E F E) \text { Matrix }\end{array}$} & \multicolumn{2}{|c|}{$\begin{array}{c}\text { Competitive Profile Matrix } \\
(C P M)\end{array}$} & \multicolumn{2}{|c|}{$\begin{array}{l}\text { Internal Evaluation } \\
\text { (IFE) Matrix }\end{array}$} \\
\hline \multicolumn{6}{|c|}{ The Matching Stage } \\
\hline $\begin{array}{c}\text { Strength- } \\
\text { Weaknesses- } \\
\text { Opportunities- } \\
\text { Threats (SWOT) } \\
\text { Matrix }\end{array}$ & $\begin{array}{r}\text { Stro } \\
\text { Positi } \\
A c \\
\text { Eval } \\
(S P \\
M c\end{array}$ & $\begin{array}{l}\text { egic } \\
n \text { and } \\
\text { on } \\
\text { ation } \\
\text { CE) } \\
\text { rix }\end{array}$ & $\begin{array}{c}\text { Boston } \\
\text { Consulting } \\
\text { Group }(B C G) \\
\text { Matrix }\end{array}$ & $\begin{array}{c}\text { Internal- } \\
\text { External (IE) } \\
\quad \text { Matrix }\end{array}$ & $\begin{array}{l}\text { Grand } \\
\text { Strategy }\end{array}$ \\
\hline \multicolumn{6}{|c|}{ The Decision Stage } \\
\hline & & & c Planning $\Lambda$ & $x / O \mathrm{C}$ & \\
\hline
\end{tabular}

Sumber: David, 2011

Ketiga tahap dalam Comprehensive Strategy Formulation Framework, yaitu:

1. The Input Stage

2. The Matching Stage

3. The Decision Stage
: Tahap Pengumpulan Data

: Tahap Penyesuaian Data

: Tahap Pengambilan Keputusan.

The Input Stage merupakan tahap pengumpulan data yang terdiri dari analisis lingkungan bisnis. Lingkungan bisnis merupakan faktor-faktor yang berada 
di luar (eksternal) atau di dalam (internal) perusahaan yang dapat mempengaruhi organisasi tersebut dalam mencapai tujuan yang telah ditetapkannya.

The Matching Stage merupakan tahap penyesuaian dalam kerangka formulasi strategi yang terdiri dari lima teknik yang dapat digunakan dalam situasi apapun, yaitu: matriks SWOT, matriks SPACE, matriks BCG, matriks IE, dan matriks Grand Strategy. Kelima teknik ini mengandalkan informasi yang didapatkan dari tahap pertama, yaitu tahap input data. Hal ini dimaksudkan sebagai proses penyesuaian antara peluang dan ancaman eksternal dengan kekuatan dan kelemahan internal. Penyesuaian antara faktor-faktor kritikal eksternal dan internal merupakan kunci untuk menghasilkan beberapa alternatif strategi yang layak (David, 2011).

The Decision Stage atau tahap pengambilan keputusan akan dilakukan dengan menggunakan Quantitative Strategic Planning Matrix (QSPM). QSPM menggunakan hasil analisis lingkungan dari tahap pertama dan hasil pencocokan dari analisis tahap kedua untuk secara objektif menentukan strategi yang hendak dijalankan di antara strategi-strategi alternatif. QSPM adalah alat yang memungkinkan para penyusun strategi mengevaluasi berbagai strategi alternatif secara objektif, berdasarkan faktor-faktor keberhasilan ekternal dan internal penting yang telah diidentifikasi sebelumnya.

\section{METODE PENELITIAN}

\section{Objek Penelitian}

Objek penelitian ini adalah PD Waringin, merupakan perusahaan keluarga yang berlokasi di Bandung, bergerak di bidang produksi pakan ternak buatan. PDW berdiri sejak tahun 1990 dengan memproduksi pakan ternak untuk ayam dan pada tahun 2000 PD Waringin mulai memfokuskan diri untuk memproduksi pakan ikan saja khususnya ikan air tawar.

\section{Metode Penelitian}

Metode yang digunakan dalam penelitian ini adalah dengan studi deskriptif kualitatif. Studi deskriptif bertujuan untuk memberikan kepada peneliti sebuah riwayat atau untuk menggambarkan aspek-aspek yang relevan dengan fenomena perhatian dari perspektif seseorang, organisasi, orientasi industri, atau lainnya (Sekaran, 2015). 


\section{Jenis dan Sumber Data}

Data yang digunakan dalam penelitian ini berupa data primer dan data sekunder. Data primer diperoleh melalui wawancara kepada pemilik dan membagikan kuisioner kepada konsumen PD Waringin. Pembagian kuisioner dilakukan untuk membandingkan hasil wawancara dari pihak perusahaan dengan pendapat dari para konsumen yang telah menggunakan produk pakan ikan PD Waringin. Fokus dari pertanyaan kuisioner adalah hal-hal yang berkaitan dengan bauran pemasaran 4P yang dilakukan perusahaan.

Penentuan jumlah sampel dalam pembagian kuisioner ini dilakukan dengan teknik purposive sampling. Purposive sampling merupakan teknik penentuan sampel dengan pertimbangan khusus sehingga layak dijadikan sampel (Sarwono, 2006). Menurut Sekaran (2015), penelitian kualitatif membutuhkan jumlah sampel kecil antara 10 sampai 20. Dalam penelitian ini kuisioner akan dibagikan kepada 15 orang konsumen PD Waringin. Kuisioner berisi beberapa pernyataan mengenai bauran pemasaran yang disajikan dalam bentuk skala likert.

Data sekunder diperoleh dari dokumen perusahaan sebagai sumber internal, internet, dan lembaga penyedia data sekunder misalnya Badan Pusat Satistik dan Kementrian Kelautan dan Perikanan serta dokumen lain yang terkait dengan penelitian.

\section{Metode Pengolahan Data}

Perumusan strategi untuk PD Waringin akan dilakukan menggunakan metode Comprehensive Strategy Formulation Framework, yang terdiri dari tiga tahap, yaitu The Input Stage, The Matching Stage, dan The Decision Stage.

1. The Input Stage, dilakukan pengumpulan data lingkungan eksternal makro, lingkungan eksternal industri, dan lingkungan internal perusahaan. Analisa lingkungan eksternal yang dilakukan mengacu pada PESTL Analysis dan Porter's 5 Forces Analysis untuk selanjutnya diolah menggunakan matriks Evaluation Factor External (EFE Matrix). Sedangkan analisa lingkungan internal meliputi aspek sumber daya, kapabilitas, dan kompetensi perusahaan. Data internal ini kemudian akan dioleh menggunakan matriks Evaluation Factor Internal (IFE Matrix)

2. The Matching Stage, dilakukan dengan menyusun matriks SWOT.

3. The Decision Stage, dilakukan dengan menggunakan Quantitative Strategic Planning Matrix (QSPM).

HASIL DAN PEMBAHASAN 


\section{Strategi Pemasaran PD Waringin Saat Ini}

Pada sub bab ini akan diuraikan mengenai aspek bauran pemasaran serta aspek segmenting, targeting, dan positioning PD Waringin saat ini.

\section{Bauran Pemasaran Saat Ini} dari:

Bauran pemasaran yang telah diterapkan oleh PD Waringin saat ini terdiri

\section{Product / Produk}

PD Waringin memproduksi pakan ikan berbentuk tepung dan pelet yang ditujukan untuk jenis ikan konsumsi seperti ikan lele, ikan mas, ikan nila, ikan kakap, dan jenis ikan konsumsi lainnya. Nama pakan ikan yang dikenal oleh konsumen saat ini sama seperti nama perusahaan yaitu pakan ikan Waringin.

2. Price / Harga

Dalam menetapkan harga jual, PD Waringin menerapkan metode cost based pricing yaitu dengan cara menambahkan biaya produksi dengan margin keuntungan yang dikehendaki. Berikut adalah harga jual dari produk pakan ikan yang ditawarkan oleh PD Waringin:

Tabel 2

Daftar Harga Pakan Ikan PD Waringin

\begin{tabular}{ccc}
\hline Jumlah & \multicolumn{2}{c}{ Bentuk Pakan Ikan } \\
\cline { 2 - 3 } Pembelian & Tepung & Pelet \\
\hline$<=3$ ton & Rp. 4.500,-/kg & Rp. $6.500,-/ \mathrm{kg}$ \\
$>3$ ton & Rp. 4.000,-/kg & Rp. 6.000,-/kg \\
\hline Sumber: Internal perusahaan, 2017
\end{tabular}

3. Place / Tempat (Distribusi)

PD Waringin berlokasi di tengah kota Bandung tepatnya berlokasi di Jalan Budiman no 65, Waringin dekat dengan Pasar Andir sebagai salah satu pusat keramaian di kota Bandung.

4. Promotion / Promosi

Promosi yang terjadi pada PD Waringin saat ini adalah word of mouth. Pemilik mengungkapkan bahwa saat ini tidak menyediakan dana khusus untuk kegiatan promosi.

\section{Segmenting, Targeting, Positioning}

Segmentasi pasar yang digunakan oleh PD Waringin didasarkan pada aspek geografis dan demografis. Saat ini PD Waringin berfokus pada konsumen di daerah Jawa Barat. Wilayah geografis Jawa Barat dapat dikelompokkan menjadi 
18 kabupaten dan 9 kota. Sedangkan aspek demografis untuk bisnis pakan ikan PD Waringin meliputi mata pencaharian dan kelas sosial.

PD Waringin menargetkan semua konsumen yang berada di wilayah Jawa Barat dengan yang diutamakan di daerah kabupaten. Wilayah ini dipilih sebagai target karena Jawa Barat terutama daerah kabupaten juga memiliki banyak lokasi budidaya ikan yang cukup potensial. Pada segmentasi demografis, PD Waringin menargetkan semua konsumen dengan segala jenis mata pencaharian dan memiliki ketertarikan pada perikanan. Dari sisi kelas sosial, dengan mempertimbangkan harga produk yang ditawarkan yaitu lebih murah bila dibandingkan dengan pakan ikan buatan pabrik pada umumnya, PD Waringin menargetkan konsumen dengan kelas sosial menengah ke bawah.

Sejak awal berdirinya di tahun 1990, PD Waringin memposisikan dirinya sebagai penyedia makanan ternak terbaik. Tagline "Makanan Ternak Terbaik" digunakan oleh perusahaan untuk memposisikan dirimya sebagai penyedia makanan ternak terbaik.

\section{Analisa Lingkungan Eksternal}

Dari hasil analisa lingkungan eksternal yang mengacu pada PESTL Analysis dan Porter's 5 Forces Analysis diketahui bahwa PD Waringin memiliki peluang (opportunities) dan ancaman (threats) sebagai berikut:

\section{Peluang (Opportunities)}

- Kebijakan Gerpari (Gerakan Pakan Ikan Mandiri) yang diterapkan oleh pemerintah dalam rangka untuk menekan biaya produksi dalam budidaya ikan mendukung para produsen pakan ikan lokal agar dapat menghasilkan produk dengan harga jual yang murah dengan cara menggunakan bahan baku lokal.

- Kebijakan pemberantasan penangkapan ikan secara ilegal (illegal fishing) membuat ketersediaan tepung ikan sebagai salah satu bahan baku pakan ikan menjadi melimpah dan harganya lebih murah daripada tepung ikan impor.

- Pada tahun 2017 Kementrian Perikanan dan Kelautan menargetkan tingkat konsumsi ikan masyarakat Indonesia berada di angka $43 \mathrm{~kg}$ per kapita per tahun. Peningkatan target konsumsi ikan tentunya akan berdampak pada meningkatnya pula kebutuhan pakan ikan dalam budidaya ikan.

- Bahan baku produk pakan ikan sebagian besar terdiri dari limbah industri yaitu bungkil tepung ikan, tepung darah sapi, kedelai, dedak padi, bungkil kelapa, dan BS makanan ringan. Bahan baku yang berasal dari limbah 
tersebut memiliki harga yang relatif murah dan dapat dengan mudah diperoleh.

- Faktor pertumbuhan penduduk juga mendorong peningkatan jumlah kebutuhan hidup antara lain membutuhkan pangan hewani seperti ikan. Peningkatan konsumsi ikan di Indonesia tentunya akan berdampak pula pada meningkatnya kebutuhan pakan ikan.

- Pakan alami sebagai produk subtitusi bersifat musiman sehingga pada saat tertentu sulit didapat dan membutuhkan pemeliharaan khusus untuk menumbuhkannya. Ketersediaan produk subtitusi yang terbatas ini memberikan peluang bagi pakan ikan buatan untuk dapat semakin berkembang.

\section{Ancaman (Threats)}

- Saat ini produk pakan ikan PD Waringin mengalami persaingan yang cukup kuat dengan pakan ikan yang diproduksi oleh pabrik seperti Cahroen Pokphand, Cargil Indonesia, Japfa Comfeed, Sinta Prima Feedmill, dan pabrik lainnya. Para penjual pakan ikan di kota Bandung cenderung untuk menjual pakan hasil buatan pabrik daripada memproduksinya sendiri.

- Penerapan program Gerpari oleh pemerintah menyebabkan ersaingan tidak hanya muncul dari sesama produsen untuk memproduksi pakan dengan harga yang lebih murah, namun dapat juga muncul dari para pembudidaya ikan yang berusaha untuk mengurangi pembelian pakan ikan dan mencoba untuk memproduksi pakan ikan secara mandiri.

- Pada musim kemarau panjang yang disertai dengan kekeringan membuat debit air akan berkurang dan mengakibatkan penurunan produksi ikan budidaya. Dampak ini kemudian akan berlanjut pada penurunan permintaan pakan ikan.

- Dalam budidaya ikan, penggunaan pakan buatan dapat digantikan dengan pakan alami yaitu cacing, ikan hidup, larva, jentik nyamuk, dan binatang renik lainnya. Keberadaan pakan alami dapat mengancam pakan ikan buatan.

\section{Analisa Lingkungan Eksternal}

Dari hasil analisa lingkungan internal yang meliputi aspek sumber daya, kapabilitas, dan kompetensi perusahaan diketahui bahwa PD Waringin memiliki kekuatan (strength) dan kelemahan (weakness) sebagai berikut: 


\section{Kekuatan (Strength)}

- Pengetahuan dan pengalaman pemilik maupun karyawan PD Waringin saat ini dianggap cukup baik mengingat perusahaan ini sudah berdiri sejak 1990 dan telah melewati berbagai peristiwa dalam proses perkembangannya.

- Konsumen berpendapat bahwa jaminan dan pelayanan yang diberikan perusahaan saat ini sudah baik.

- Harga jual yang ditawarkan oleh PD Waringin terbilang cukup murah bila dibandingkan dengan produk pesaing yaitu pakan ikan buatan pabrik yang harga jualnya bisa mencapai Rp 9.000,-/kg hingga Rp 11.000,-/kg.

- PD Waringin memiliki hubungan yang baik dengan konsumennya.

- Konsumen menilai PD Waringin memiliki ketersediaan produk yang cukup untuk memenuhi kebutuhan konsumen dan pengiriman barang selalu dilakukan tepat waktu.

- Kemampuan sumber daya manusia yang dimiliki PD Waringin dapat dikatakan baik dan hampir setara dengan sumber daya manusia yang dimiliki oleh pesaing. Para karyawan PD Waringin cukup memahami dengan baik proses produksi pakan ikan dan mengetahui standar-standar yang harus dicapai di setiap tahapan prosesnya.

\section{Kelemahan (Weakness)}

- Mesin-mesin produksi yang digunakan saat ini dapat dinilai cukup baik meskipun diakui oleh pemilik bahwa teknologi dari mesin-mesin tersebut masih tertinggal dari para pesaingnya.

- Lokasi perusahaan saat ini dirasakan oleh pemilik menimbulkan kesulitan dalam hal pengangkutan barang yang disebabkan oleh kemacetan lalu lintas di sekitar pasar.

- PD Waringin memiliki variasi produk yang terbatas, yaitu hanya memproduksi satu jenis produk sementara para pesaingnya memiliki beberapa variasi produk pakan ikan dan juga menyediakan produk lain seperti obat atau vitamin ikan.

- PD Waringin tidak memberikan desain khusus untuk kemasannya. Pemilik mengakui bahwa perusahaan tidak memberikan perhatian khusus untuk desain dan bentuk kemasan produk. Hal ini dimaksudkan untuk mengurangi biaya produksi agar harga jual produk bisa tetap murah.

- Dalam hal promosi, konsumen menilai bahwa promosi yang dilakukan oleh PD Waringin saat ini masih kurang. Perusahaan jarang membuat iklan mengenai produknya sehingga konsumen sulit mendapatkan informasi yang lengkap mengenai produk pakan ikan PD Waringin.

- Saat ini PD Waringin belum memiliki divisi khusus penelitian dan pengembangan. Penelitian dan pengembangan produk saat ini masih 
dilakukan sepenuhnya oleh pemilik. Perusahaan tidak menyediakan dana dan waktu khusus untuk melakukan penelitian dan pengembangan.

\section{The Input Stage}

Berdasarkan hasil analisis lingkungan eksternal dan internal pada uraian sebelumnya didapatkan matriks evaluasi faktor eksternal (EFE Matrix) dan matriks evaluasi faktor internal (IFE Matrix). Bobot dan peringkat pada matriks diperoleh dengan mempertimbangkan data-data yang diperoleh dari hasil wawancara kepada pemilik PD Waringin, serta mempertimbangkan pula hasil kuisioner yang disebarkan kepada konsumen. Berdasarkan hasil perhitungan pada matriks EFE, dapat diketahui bahwa PD Waringin memiliki nilai skor total sebesar 2,66 dan skor ini berada diatas rata-rata. Hal ini menunjukkan bahwa bisnis pakan ikan PD Warigin saat ini berjalan cukup baik, perusahaan dapat memanfaatkan peluang eksternal dan menghindari ancaman yang dihadapi perusahaan.

Tabel 3

Matriks EFE PD Waringin

\begin{tabular}{|c|c|c|c|c|}
\hline Faktor-faktor Eksternal & $\begin{array}{l}\text { Bobot } \\
\text { (a) }\end{array}$ & $\begin{array}{l}\text { Peringkat } \\
\text { (b) }\end{array}$ & $\begin{array}{l}\text { Skor } \\
\text { Bobot } \\
(\mathrm{a} \times \mathrm{b})\end{array}$ & Keterangan \\
\hline \multicolumn{5}{|l|}{ Peluang (Opportunities) } \\
\hline 1 Program pemerintah & 0,11 & 3 & 0,33 & Program pemerintah saat ini mendukung penggunaan pakan lokal \\
\hline 2 Bahan baku & 0,15 & 4 & 0,6 & Ketersediaan bahan baku terjamin \\
\hline 3 Potensi pertumbuhan pasar bes & 0,15 & 3 & 0,451 & Masih terdapat banyak konsumen potensial \\
\hline 4 Ketersediaan produk subtitusi & 0,1 & 3 & 0,3 & Terbatas, tergantung musim \\
\hline \multicolumn{5}{|l|}{ Ancaman (Threats) } \\
\hline 1 Jumlah pesaing & 0,15 & 2 & $0,3 \mathrm{l}$ & Pakan pabrikan semakin berkembang \\
\hline 2 Pesaing baru & 0,08 & 2 & 0,161 & Munculnya pesaing baru \\
\hline 3 Produk subtitusi & 0,08 & 2 & 0,16 & Keberadaan produk subtitusi mempengaruhi permintaan pakan buatan \\
\hline 4 Program pemerintah & 0,11 & 2 & 0,221 & Mempermudah masuknya pesaing baru \\
\hline 5 Lingkungan alam & 0,07 & 2 & 0,14 & $\begin{array}{l}\text { Musim kemarau mengganggu kegiatan budidaya ikan yang berdampak } \\
\text { pula pada penurunan permintaan pakan ikan }\end{array}$ \\
\hline Total & 1 & - & 2,66 & \\
\hline
\end{tabular}

Matriks evaluasi faktor internal (IFE Matrix) PD Waringin adalah sebagai berikut: 
Tabel 4

Matriks IFE PD Waringin

\begin{tabular}{|c|c|c|c|c|}
\hline Faktor-faktor Internal & $\begin{array}{l}\text { Bobot } \\
\text { (a) }\end{array}$ & $\begin{array}{l}\text { Peringkat } \\
\text { (b) }\end{array}$ & $\begin{array}{c}\text { Skor } \\
\text { Bobot } \\
(\mathrm{a} \times \mathrm{b})\end{array}$ & Keterangan \\
\hline \multicolumn{5}{|l|}{ Kekuatan (Strength) } \\
\hline 1 Pengetahuan dan pengalaman & 0,08 & 4 & $4 \quad 0,32$ & Memiliki pengetahuan dan pengalaman yang memadai \\
\hline 2 Jaminan produk & 0,07 & 3 & $3 \quad 0,21$ & Baik, bertanggung jawab pada kualitas produk \\
\hline 3 Pelayanan konsultasi & 0,07 & 3 & $3 \quad 0,21$ & Baik, bersedia memberikan konsultasi \\
\hline 4 Harga & 0,1 & 4 & 0,4 & Murah, lebih murah dibandingkan pesaing \\
\hline 5 Hubungan dengan konsumen & 0,07 & 4 & $4 \quad 0,28$ & Baik, memiliki beberapa konsumen tetap (konsumen langganan) \\
\hline 6 Distribusi produk & 0,07 & 4 & $4 \quad 0,28$ & Ketersediaan produk terjaga, pengiriman tepat waktu \\
\hline 7 Sumber daya manusia & 0,06 & 3 & $3 \quad 0,18$ & Turnover rendah dan ahli, mengerti standar setiap tahapan proses \\
\hline \multicolumn{5}{|l|}{ Kelemahan (Weakness) } \\
\hline 1 Teknologi & 0,06 & 2 & $2 \quad 0,12$ & Tidak memiliki daya saing teknologi \\
\hline 2 Lokasi & 0,06 & 2 & $2 \quad 0,12$ & Sulit diakses konsumen luar kota \\
\hline 3 Variasi produk & 0,07 & 1 & $1 \quad 0,07$ & Terbatas, hanya menyediakan 1 jenis produk \\
\hline 4 Kemasan produk & 0,06 & 2 & $2 \quad 0,12$ & Kurang menarik \\
\hline 5 Promosi & 0,09 & 1 & 10,09 & Pasif dibanding pesaing, mengandalkan word of mouth \\
\hline 6 Akses informasi produk & 0,07 & 1 & $1 \quad 0,07$ & Sulit mencari informasi produk \\
\hline 7 Penelitian dan pengembangan & 0,07 & 2 & $2 \quad 0,14$ & Pasif \\
\hline Total & 1 & - & 2,61 & \\
\hline
\end{tabular}

Berdasarkan hasil perhitungan pada matriks IFE, dapat diketahui bahwa PD Waringin memiliki nilai skor total sebesar 2,61. Angka ini menunjukkan bahwa PD Waringin berada pada posisi internal yang kuat. Hasil analisa matriks EFE dan IFE menunjukkan bahwa masih ada ruang untuk melakukan perbaikan mengingat skor total tertinggi adalah 4 .

\section{The Matching Stage}

Berdasarkan data yang diperoleh dari analisa terhadap lingkungan eksternal dan internal diperoleh alternatif strategi untuk PD Waringin dengan menggunakan matriks SWOT sebagai berikut.

Tabel 5

Matriks SWOT PD Waringin

\begin{tabular}{|l|l|l|}
\hline \multicolumn{2}{|c|}{ Strategi SO } & \multicolumn{2}{|c|}{ Strategi ST } \\
\hline - $\begin{array}{l}\text { Melakukan pengembangan produk } \\
\text { dengan memanfaatkan bahan baku } \\
\text { lokal (S1O2) }\end{array}$ & - $\begin{array}{l}\text { Meningkatkan hubungan baik dengan } \\
\text { konsumen agar konsumen tetap loyal } \\
\text { meskipun panyak }\end{array}$ \\
- $\begin{array}{l}\text { Meningkatkan efisiensi produksi agar } \\
\text { harga jual produk dapat tetap murah } \\
\text { (S4O1) }\end{array}$ & $\begin{array}{l}\text { bermunculan (S5T1) } \\
\text { Melakukan penelitian pasar dan }\end{array}$ \\
- Mengoptimalkan & $\begin{array}{l}\text { Meningkatkan kualitas produk untuk } \\
\text { mengetahui tingkat kualitas yang }\end{array}$ \\
\hline
\end{tabular}


CAROLINE DAN LAURA LAHINDAH

\begin{tabular}{|c|c|}
\hline Strategi SO & Strategi ST \\
\hline $\begin{array}{l}\text { penjualan dengan memperluas } \\
\text { jaringan distribusi misal menjual } \\
\text { secara online (S6O3), meningkatkan } \\
\text { pelayanan, jaminan kepada konsumen } \\
\text { (S2O3, S3O3), dan menjaga } \\
\text { hubungan baik dengan konsumen } \\
\text { (S5O3) } \\
\text { Meningkatkan produktivitas agar } \\
\text { dapat memenuhi kebutuhan } \\
\text { konsumen dan produk yang dihasilkan } \\
\text { semakin berkualitas (S7O4) }\end{array}$ & $\begin{array}{l}\text { dibutuhkan konsumen agar } \\
\text { konsumen tidak beralih ke produk } \\
\text { subtitusi (S1T3) } \\
\text { Meningkatkan efisiensi agar harga } \\
\text { tetap murah, meningkatkan } \\
\text { ketersediaan produk, dan } \\
\text { meningkatkan kecepatan pelayanan } \\
\text { agar pembudidaya tetap memilih } \\
\text { untuk membeli daripada } \\
\text { memproduksi pakan ikan secara } \\
\text { mandiri (S4T4, S6T4) }\end{array}$ \\
\hline & Strategi WT \\
\hline 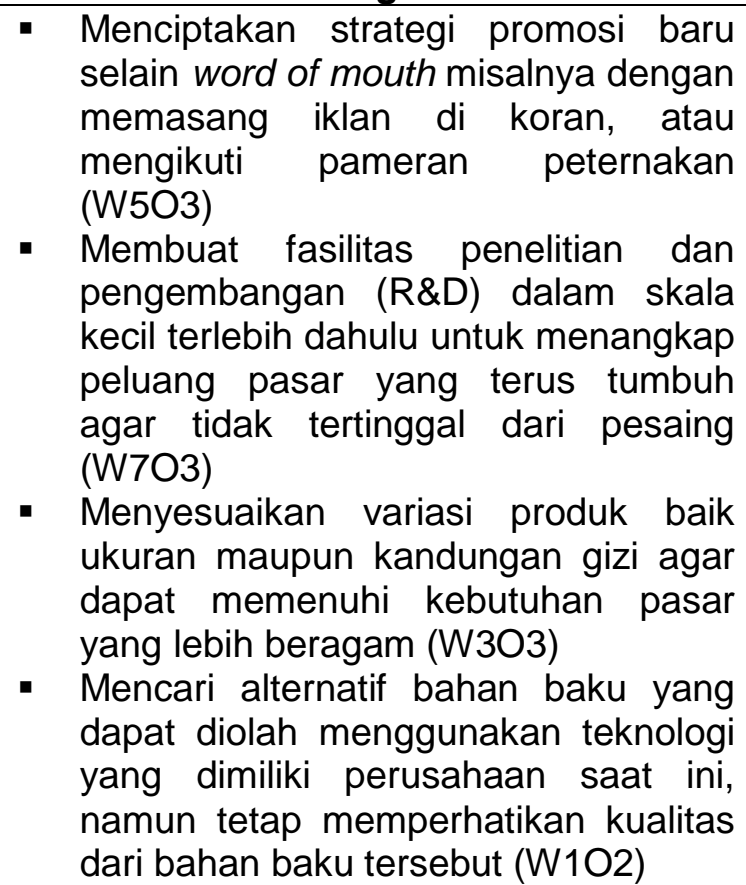 & 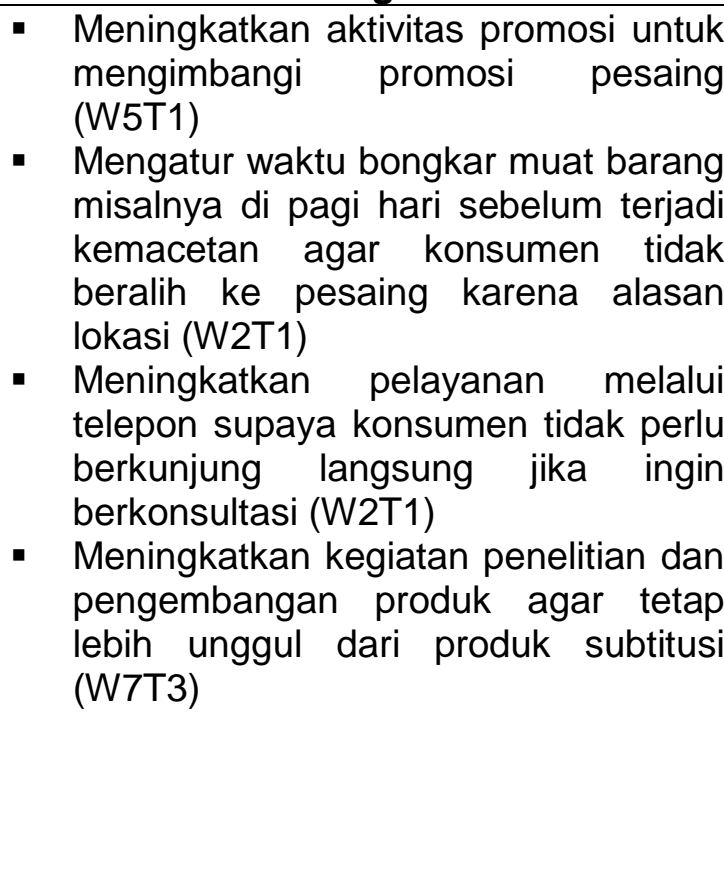 \\
\hline
\end{tabular}

\section{The Decision Stage}

Dalam rangka menentukan alternatif strategi yang paling menarik, alternatif strategi pada tahap SWOT selanjutnya diolah menggunakan matriks Quantitative Strategic Planning (QSPM). 
Tabel 6

Matriks QSPM PD Waringin

\begin{tabular}{|c|c|c|c|c|c|c|c|c|c|c|}
\hline \multirow[b]{3}{*}{ No. } & \multirow[b]{3}{*}{ Faktor Kunci } & \multirow[b]{3}{*}{ Bobot } & \multicolumn{8}{|c|}{ Alternatif Strategi } \\
\hline & & & \multicolumn{2}{|c|}{ Strategi SO } & \multicolumn{2}{|c|}{ Strategi ST } & \multicolumn{2}{|c|}{ Strategi WO } & \multicolumn{2}{|c|}{ Strategi WT } \\
\hline & & & $\begin{array}{l}\text { Skor } \\
\text { Daya } \\
\text { Tarik } \\
\text { (AS) }\end{array}$ & $\begin{array}{l}\text { Total } \\
\text { Skor } \\
\text { Daya } \\
\text { Tarik } \\
\text { (TAS) }\end{array}$ & $\begin{array}{l}\text { Skor } \\
\text { Daya } \\
\text { Tarik } \\
\text { (AS) }\end{array}$ & $\begin{array}{c}\text { Total } \\
\text { Skor } \\
\text { Daya } \\
\text { Tarik } \\
\text { (TAS) }\end{array}$ & $\begin{array}{l}\text { Skor } \\
\text { Daya } \\
\text { Tarik } \\
\text { (AS) }\end{array}$ & $\begin{array}{l}\text { Total } \\
\text { Skor } \\
\text { Daya } \\
\text { Tarik } \\
\text { (TAS) }\end{array}$ & $\begin{array}{l}\text { Skor } \\
\text { Daya } \\
\text { Tarik } \\
\text { (AS) }\end{array}$ & $\begin{array}{l}\text { Total } \\
\text { Skor } \\
\text { Daya } \\
\text { Tarik } \\
\text { (TAS) }\end{array}$ \\
\hline & $\begin{array}{l}\text { Peluang } \\
\text { (Opportunities) }\end{array}$ & & & & & & & & & \\
\hline 1 & Program pemerintah & 0,11 & 3 & 0,33 & 3 & 0,33 & 1 & 0,11 & 1 & 0,11 \\
\hline 2 & Bahan baku & 0,15 & 4 & 0,6 & 3 & 0,45 & 4 & 0,6 & 2 & 0,3 \\
\hline 3 & $\begin{array}{l}\text { Potensi pertumbuhan } \\
\text { pasar besar }\end{array}$ & 0,15 & 4 & 0,6 & 3 & 0,45 & 4 & 0,6 & 3 & 0,45 \\
\hline 4 & $\begin{array}{l}\text { Ketersediaan produk } \\
\text { subtitusi } \\
\text { Ancaman (Threats) }\end{array}$ & 0,1 & 2 & 0,2 & 2 & 0,2 & 3 & 0,3 & 3 & 0,3 \\
\hline 1 & Jumlah pesaing & 0,15 & 3 & 0,45 & 3 & 0,45 & 3 & 0,45 & 4 & 0,6 \\
\hline 2 & Pesaing baru & 0,08 & 2 & 0,16 & 3 & 0,24 & 1 & 0,08 & 3 & 0,24 \\
\hline 3 & Produk subtitusi & 0,08 & 2 & 0,16 & 3 & 0,24 & 2 & 0,16 & 3 & 0,24 \\
\hline 4 & Program pemerintah & 0,11 & 3 & 0,33 & 4 & 0,44 & 1 & 0,11 & 2 & 0,22 \\
\hline \multirow[t]{2}{*}{5} & Lingkungan alam & $\begin{array}{r}0,07 \\
1\end{array}$ & 1 & 0,07 & 1 & 0,07 & 1 & 0,07 & 1 & 0,07 \\
\hline & Kekuatan (Strength) & & & & & & & & & \\
\hline 1 & $\begin{array}{l}\text { Pengetahuan dan } \\
\text { pengalaman }\end{array}$ & 0,08 & 3 & 0,24 & 4 & 0,32 & 4 & 0,32 & 3 & 0,24 \\
\hline 2 & Jaminan produk & 0,07 & 2 & 0,14 & 2 & 0,14 & 2 & 0,14 & 2 & 0,14 \\
\hline 3 & Pelayanan konsultasi & 0,07 & 2 & 0,14 & 3 & 0,21 & 2 & 0,14 & 4 & 0,28 \\
\hline 4 & Harga & 0,1 & 4 & 0,4 & 4 & 0,4 & 2 & 0,2 & 1 & 0,1 \\
\hline 5 & $\begin{array}{l}\text { Hubungan dengan } \\
\text { konsumen }\end{array}$ & 0,07 & 3 & 0,21 & 4 & 0,28 & 3 & 0,21 & 4 & 0,28 \\
\hline 6 & Distribusi produk & 0,07 & 3 & 0,21 & 4 & 0,28 & 1 & 0,07 & 3 & 0,21 \\
\hline 7 & $\begin{array}{l}\text { Sumber daya manusia } \\
\text { Kelemahan (Weakness) }\end{array}$ & 0,06 & 4 & 0,24 & 4 & 0,24 & 3 & 0,18 & 3 & 0,18 \\
\hline 1 & Teknologi & 0,06 & 4 & 0,24 & 4 & 0,24 & 4 & 0,24 & & 0 \\
\hline 2 & Lokasi & 0,06 & 1 & 0,06 & 1 & 0,06 & 1 & 0,06 & 4 & 0,24 \\
\hline 3 & Variasi produk & 0,07 & 3 & 0,21 & 1 & 0,07 & 4 & 0,28 & 2 & 0,14 \\
\hline 4 & Kemasan produk & 0,06 & 1 & 0,06 & 1 & 0,06 & 4 & 0,24 & 1 & 0,06 \\
\hline 5 & Promosi & 0,09 & 4 & 0,36 & 3 & 0,27 & 4 & 0,36 & 4 & 0,36 \\
\hline 6 & $\begin{array}{l}\text { Akses informasi } \\
\text { produk }\end{array}$ & 0,07 & 4 & 0,28 & 3 & 0,21 & 4 & 0,28 & 4 & 0,28 \\
\hline 7 & $\begin{array}{l}\text { Penelitian dan } \\
\text { pengembangan }\end{array}$ & 0,07 & 4 & 0,28 & 4 & 0,28 & 4 & 0,28 & 4 & 0,28 \\
\hline
\end{tabular}

Hasil analisa matriks QSPM menunjukkan bahwa alternatif strategi yang paling menarik adalah strategi SO dengan nilai skor total terbesar yaitu 5,97. Dalam strategi SO, PD Waringin disarankan untuk menggunakan kekuatankekuatan yang dimilikinya saat ini untuk memanfaatkan peluang-peluang yang 
ada. Adapun alternatif strategi yang diusulkan dalam startegi SO adalah sebagai berikut.

1. Melakukan pengembangan produk dengan memanfaatkan bahan baku lokal (S1O2)

Saat ini pemerintah sedang menekankan kebijakan penggunaan pakan ikan mandiri yang dibuat dari bahan baku lokal dalam rangka untuk mengurangi biaya produksi dalam budidaya ikan. Pengetahuan dan pengalaman yang dimiliki perusahaan selama ini disarankan untuk semakin diperdalam dan diterapkan untuk dapat menghasilkan produk pakan ikan yang semakin berkualitas dengan memanfaatkan bahan baku lokal.

2. Meningkatkan efisiensi produksi agar harga jual produk dapat tetap murah (S4O1)

Sejalan dengan program pemerintah untuk mengurangi biaya produksi dalam budidaya ikan, tentunya harga pakan ikan yang murah pun akan semakin dicari. Pakan ikan PD Waringin tidak dibuat dari bahan baku impor yang harganya mahal, melainkan dibuat dari bahan baku lokal yang dapat mudah diperoleh di dalam negri dengan harga yang murah serta proses produksinya yang masih sederhana. PD Waringin diharapkan dapat meningkatkan kembali efisiensi produksinya agar harga jual pakan ikan dapat tetap murah.

3. Mengoptimalkan pertumbuhan penjualan dengan memperluas jaringan distribusi misal menjual secara online (S6O3), meningkatkan pelayanan, jaminan kepada konsumen (S2O3, S3O3), dan menjaga hubungan baik dengan konsumen (S5O3).

Perusahaan disarankan untuk mengoptimalkan penjualannya dengan cara memperluas jaringan distribusi. Hal ini perlu dilakukan karena sebenarnya potensi perkembangan usaha pakan ikan di Indonesia masih sangat besar mengingat Indonesia masih memiliki potensi area budidaya ikan yang luas, serta kebijakan pemerintah dalam bidang perikanan saat ini sangat mendukung pelaku usaha pakan ikan lokal.

4. Meningkatkan produktivitas agar dapat memenuhi kebutuhan konsumen dan produk yang dihasilkan semakin berkualitas (S7O4)

Keberadaaan produk subtitusi dapat menjadi ancaman namun dapat juga menjadi peluang jika ketersediaan produk subtitusi tersebut terbatas. PD Waringin disarankan untuk semakin meningkatkan produktivitasnya agar dapat senantiasa memenuhi kebutuhan konsumen dan diharapkan konsumen akan tetap tertarik untuk menggunakan pakan ikan buatan daripada pakan ikan alami. Peningkatan produktivitas ini tidak terlepas dari peran sumber daya manusia.

\section{KESIMPULAN DAN SARAN}




\section{Kesimpulan}

Alternatif strategi yang paling menarik untuk PD Waringin saat ini adalah strategi SO (Strength-Opportunities). Dalam strategi SO, PD Waringin disarankan untuk menggunakan kekuatan-kekuatan yang dimilikinya saat ini untuk memanfaatkan peluang-peluang yang ada. Adapun beberapa strategi yang diusulkan dalam strategi SO adalah melakukan pengembangan produk, meningkatkan efisiensi produksi, mengoptimalkan pertumbuhan penjualan dengan memperluas jaringan distribusi, misal menjual secara online, meningkatkan pelayanan, jaminan kepada konsumen, dan menjaga hubungan baik dengan konsumen, dan meningkatkan produktivitas agar dapat memenuhi kebutuhan konsumen dan produk yang dihasilkan semakin berkualitas.

\section{Saran}

Untuk penelitian selanjtnya, perumusan strategi untuk PD Waringin belum mempertimbangkan aspek keuangan sehingga masih ada pertimbanganpertimbangan yang belum terakomodir dalam penelitian ini. Penelitian selanjutnya diharapkan dapat melibatkan aspek keuangan sehingga dapat melengkapi hasil penelitian ini. Untuk perusahaan, agar alternatif strategi yang diusulkan dalam penelitian ini dapat terlaksana dengan baik, diperlukan kesungguhan dari berbagai pihak yang terlibat dalam perusahaan.

\section{REFERENSI}

Afrianto, Eddy dan Evi Liviawaty. (2005). Pakan Ikan : Pembuatan, Penyimpanan, Pengujian, Pengembangan. Kanisius.

Badan Pusat Statistik (2016)

David, \& Fred, R. (2011). Strategic Management: Concepts \& Cases $13^{\text {th }}$ Edition. Prentice Hall, Inc.

Dolan, Robert J. (2014). Framework for Marketing Strategy Formation. Harvard Bussiness School Publishing.

Ferrel, O.C dan Michael Hartline. (2011). Marketing Strategy: Text and Cases $6^{\text {th }}$ Ed. South Western Cengage Learning, USA.

Kementrian Kelautan dan Perikanan. (2016) Informasi Kelautan dan Perikanan Bulan Januari 2016 No. 01/PUSDATIN///2016.

Kotler, Philip dan Kevin Lane Keller. (2002). Marketing Management. 
Porter, Michael (1998). Competitive Strategy: Techniques For Analyzing Industries and Competitors. The Free Press, New York.

Porter, Michael (1998). Competitive Advantage: Creating and Sustaining Superior Performance. The Free Press, New York.in

Prasetya, B dan Tim Penulis CMK. (2015). Panduan Praktis Pakan Ikan Konsumsi. Penebar Swadaya, Jakarta.

Putra, Muhammad Firman Eko. (2016). Target Ekspor Perikanan Tahun 2017 Sebesar 76 Miliar Dolar. katadata.co.id

Sadler, Philip. (2003). Strategic Management $2^{\text {nd }}$ Edition. Kogan Page Limited.

Sekaran, Uma. (2015). Metodologi Penelitian untuk Bisnis, Edisi ke 4. Penerbit Salemba Empat.

Wheelen, Thomas L. dan David Hunger. (2012). Strategic Management and Business Policy $13^{\text {th }}$ Ed. Pearson Education, USA.

Sujan H, Weitz, barton A, and Sujan M, (1990), "Increasing Sales Productivity by Getting Salespeople to Work Smarter", Jurnal of Personal Selling and Sales Management, August 1990.

Verbeke, Willem J; Frank D Belschak; Arnold B baker; Bart Dietz (2008), "when intelegence (Dys) functional for achieving sales performance," Journal of Marketing 